\title{
Genetic Diversity of Porang Populations (Amorphophallus Muelleri Blume) in Central Java and West Java Based on LEAFY Second Intron Marker
}

\author{
Isna Arofatun Nikmah*, Rodiyati Azrianingsih, Didik Wahyudi
}

Biology Departement, Faculty of Mathematics and Natural Sciences, Brawijaya University, Malang, Indonesia

\section{ABSTRACT}

Porang (Amorphophallus muelleri Blume) is dispersed and grew well in Java island. This research aimed to determine the genetic diversity of porang populations in Central Java and West Java based on $L E A F Y$ second intron (nuclear genome encoding flower development). DNA samples of porang were from previous study, which were obtained from Central Java (Pamedaran, Grobogan, Wonogiri, Karangtengah) and West Java (Cisompet) as in-group. Amorphophallus variabilis from Pamedaran Brebes, Amorphophallus ochroleucus, Amorphophallus longituberosus, Amorphophallus sumawongii, and Amorphophallus tinekeae from GenBank were treated as out-group. LEAFY second intron was amplified using primers FLint2 F1 5'-CTTCCACCTCTACGACCAGTG-3' and FLint2 R1 5'-TCTTGGGCTTGTTGATGTAGC-3'. Analysis using dnasp5 showed that 23 samples had 89 invariable sites and 139 variable sites that consisted of 12 singletons two variants sites, 118 parsimony-informative two variants sites, and 9 Parsimony-infor mative three variants sites. The total of haplotype were seven haplotypes where 16 in-group samples clumped on haplotype 1 whereas two samples of Grobogan (Grobogan I and Grobogan III) clumped on haplotype 2, and out-group samples occupied at their own haplotype. The genetic distance of all in-group samples was 0-0,004 showing no differences among individuals. Analysis of phyloge netic tree using Maximum Parsimony, Neighbor Joining and Maximum Likelihood resulting a polytomy branch of in-group samples except Grobogan, which forms a separated sub-clade.

Keywords: Genetic diversity, haplotype, Java, LEAFY, Porang

\section{INTRODUCTION}

Porang (Amorphophallus muelleri Blume) was placed in the family Araceae, which is characterized by spathe and spadix. Porang can reproduce vegetatively using tuber, and bulbils and generatively with seed. Bulbils, appear on the top of petioles is a special character of porang which differentiates porang with other genera of Amorphophallus [1].

Amorphophallus muelleri, first recorded in the Andaman Islands of India. Then it was predicted to disperse to the east through Myanmar and into Thailand toward Indonesia. In Indonesia, porang occurs wild and cultivated in Sumatra, Madura, Bali, Nusa Tenggara Barat (NTB) and mostly distributed in Java [2]. In Java, porang can grow in some areas in East Java such as in Jember, Malang, Blitar, Nganjuk, Madiun and

\footnotetext{
${ }^{*}$ Corresponding author:

Isna Arofatun Nikmah

Biology Departement, Faculty of Mathematics and Natural

Sciences, Brawijaya University

Jl. Veteran, Malang 65145, Indonesia

E-mail: isnaarofatun@gmail.com
}

Bojonegoro [3]. In Central Java, porang were found in Karangtengah Wonogiri, Grobogan, Brebes, Lebak Barang Pekalongan and Tegal. In West Java can be found in Cisompet Garut, Tjikirai, Tjibadak, Halimun and Tarogong Garut $[4,5]$.

Porang in Java had a high population genetic diversity [6]. Morphological and molecular markers usually applied in the study of genetic diversity. Morphological markers have been widely used, but generally influenced by environments, so it can be difficult to observe the differences between closely related species. Therefore, molecular markers can solve this problem [7].

Molecular markers which is used to analyze phylogenies of plants are from chloroplast and nuclear genomes. Molecular marker from chloroplast genome consist of matK, rbcL, trnK intron, trnL intron, trnLtrnF [8], whereas from nuclear genome consists of ITS1, ITS2 [9] and $L E A F Y$ [8]. $L E A F Y$ is a gene that play an important role in flower development [10].

$L E A F Y$ contains two introns and three exons. Since introns are known evolved faster than exons and $L E A F Y$ second intron was more variable than the first 
intron, $L E A F Y$ second intron can be useful for reconstructing phylogenies of closely related species $[11,12]$.

Previous study of genetic diversity of porang in Central Java and West Java only used trnL intron from the chloroplast genome as marker. Chloroplast genome is derived uniparental and has a lower genetic diversity than the nuclear genome that is biparental (has a genetic recombination of two parental). Therefore, nuclear genomes can provide more appropriate information for the study of Angiosperms phylogenies [13].

Study of genetic diversity of porang is important in porang breeding programs, so in this study we examine the genetic diversity of porang populations in Java using $L E A F Y$ second intron sequence.

\section{MATERIALS AND METHODS DNA samples}

DNA samples were from previous research [4] which were isolated from young leaves taken from Central Java that consist of three individuals from Wonogiri, three individuals from Karangtengah, three individuals from Pamedaran Brebes, three individuals from Grobogan and three individuals from West Java (Cisompet) as in-group, while out-group samples were $L E A F Y$ second intron of Amorphophallus variabilis from Pamedaran Brebes and $L E A F Y$ second intron of Amorphophallus ochroleucus, Amorphophallus longituberosus, Amorphophallus sumawongii, and Amorphophallus tinekeae from GenBank (Table 1).

Table 1. Access code in GenBank Amorphophallus ochroleucus, Amorphophallus longituberosus, Amorphophallus sumawongii, and Amorphophallus tinekeae

\begin{tabular}{lll}
\hline \multicolumn{1}{c}{ Species } & Access code \\
& in & Author \\
& GeneBank & \\
\hline Amorphophallus ochroleucus & AF497018 & Grob et al. [10] \\
Amorphophallus & AF497050 & Grob et al. [10] \\
longituberosus & & \\
Amorphophallus sumawongii & AF497044 & Grob et al. [10] \\
Amorphophallus tinekeae & DQ0112481 & Grob et al. [10] \\
\hline
\end{tabular}

\section{Amplification of LEAFY second intron}

$L E A F Y$ second intron was amplified with primers FLint2 F1 5'-CTTCCACCTCT ACGACCAGTG-3' and FLint2 R1 5'-TCTTGGGCTTGTTGATGTAGC-3' [3]. $L E A F Y$ second intron was amplified for a total of $30 \mu \mathrm{L}$ mix that consisted six $\mu \mathrm{L} \mathrm{ddH}_{2} \mathrm{O}, 15 \mu \mathrm{L}$ Master
Mix, three $\mu \mathrm{L}$ forward primer dan reverse primer $(2.5$ $\mu \mathrm{M})$ and three $\mu \mathrm{L}$ DNA template. PCR reactions composed of 30 cycles with an initial denaturation at $94^{\circ} \mathrm{C}$ for $4 \mathrm{~min}$, followed by denaturation at $94^{\circ} \mathrm{C}$ for $30 \mathrm{sec}-$ onds, annealing at $62^{\circ} \mathrm{C}$ for 30 seconds, extension at $72^{\circ} \mathrm{C}$ for 30 seconds and final extension at $72^{\circ} \mathrm{C}$ for 7 $\min$.

\section{Sequencing of $L E A F Y$ second intron}

$L E A F Y$ amplicons were sequenced in a First Base, Malaysia.

\section{Data Analysis}

Sequences were analyzed using sequence scanner. The similarity of a query sequence with a library or database of sequences were analyze using BLAST. Multiple sequence alignment between $L E A F Y$ second intron made by MEGA 5.0. Sequences were edited with $B i o E d i t$ and analyzed with the dnasp5 program and haplotype network. A topology of phylogenetic was reconstructed using MEGA 5.0 and the phylogenetic tree was analyzed using Maximum Parsimony, Neighbor Joining, and Maximum Likelihood. Maximum Parsimony uses algorithmic computation models CNI (Close Neighbor Interchange) on random tree performed a total of 10 replicates. Maximum Likelihood using algorithmic calculation model HKY (Hasegawa, Kishino Yano). Phylogenetic tree was evaluated with bootstrap analysis 1000 replicates.

\section{RESULTS AND DISCUSSION \\ Genetic diversity}

Amplification using internal primers of FLint2 F1 and FLint2 R1 [10] produced an amplicon of $300 \mathrm{bp}$. $L E A F Y$ second intron sequence has a total length of base from 280 bp till 296 bp. According to Grob et al., [9] $L E A F Y$ second intron of Amorphophallus has a length of base ranged from 271-368 bp. Result of BLAST showed that sequences from this research have similarities to $L E A F Y$ second intron of $A$. muelleri by 96-99\%.

Sequences of in-group and out-group were analyzed for the total number of invariable (monomorphic) sites and variable (polymorphic) sites. Variable sites consist of singleton sites (sites that there is only one distinct taxa) and parsimony-informative sites (sites that contain at least two types of nucleotides and present at least twice). The $L E A F Y$ second intron alignment consisted of 242 characters. Of the 242 characters, 89 were invariable (monomorphic) sites and 139 variable (poly- 
morphic) sites where 12 sites are singleton two variants. Total of parsimony informative sites are 127 that consist of 118 of parsimony informative sites two variants and 9 of parsimony-informative sites three variants. Parsimony informative sites are useful for reconstructing phylogenetic tree, meanwhile singleton sites are non informative sites that cannot provide information about which are parsimonous tree [14].

The haplotype analysis of 23 samples using network program showed the separation into seven haplotypes where haplotype 1 consist of in-group samples from West Java and Central Java, except Grobogan I and Grobogan III. Samples from Grobogan I and Grobogan III separates into its own haplotype (haplotype 2). Haplotype 3, 4, 5, and 6 is $A$. ochroleucus, $A$. longituberosus, $A$. sumawongii, $A$. tinekeae from GenBank, respectively. Haplotype 7 is A. variabilis from Pamedaran Brebes (Figure 1). Based on haplotype reconstruction, porang which are on haplotype 1 and haplotype 2 are closer to $A$. variabilis than the others, but porang which are on haplotype 1 are more primitive than porang located in haplotype 2 which consists of porang from Grobogan I and III, this indicates that these two individuals are evolving faster than other ingroup samples (Figure 1). According to previous research by Wahyudi et al., [4] stated that Grobogan has higher haplotype diversity index and samples of Grobogan population were obtained from different seed of different places that were from Madiun and Pamedaran brebes. Madiun and Pamedaran Brebes allegedly have different genetic variaton.

Genetic distance between in-group samples are 0, or it can be said that there are no differences between in-group samples, except samples of Grobogan I and III which has a genetic distance of 0.004 with other ingroup samples. These data showed that all porang populations from Central Java have a very close relationship with porang population from West Java based on $L E A F Y$ second intron. The genetic distance of $\mathrm{A}$. variabilis with porang was narrow, namely 0.064 and 0.069 with samples of Grobogan I and III which indicates that $A$. variabilis of Pamedaran Brebes have a close relationship with porang. Genetic distance is used to measure the differences in genetic structure between two population at a particular gene locus. Most but not all of the genetic distance have a value between 0 and 1. The minimum value of 0 occur if genetic structure of two populations are identical, while the maximum value of 1 indicates that two populations do not share any genetic type [15].

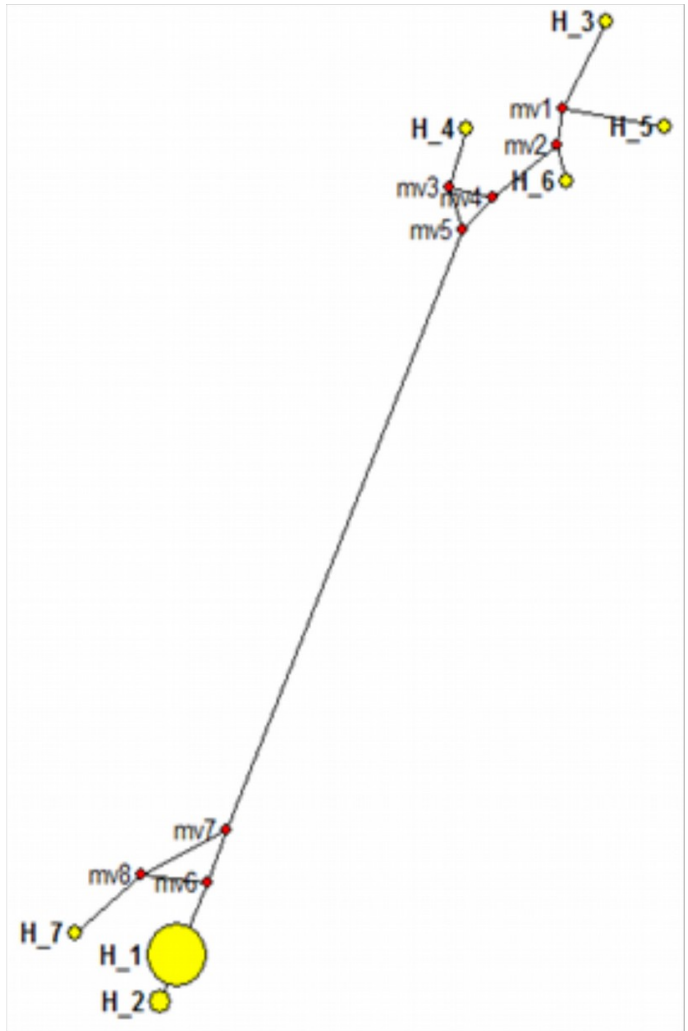

Figure 1. Haplotype of in-group and out-group samples

\section{Phylogeny of Amorphophallus muelleri Maximum parsimony}

Maximum parsimony method produces a polytomy in tree topology of in-group samples with a bootstrap value of 97. Meanwhile, A. variabilis Pamedaran Brebes become the most primitive out-group than other outgroups. Individuals from Grobogan I and III Grobogan form a separate sub-clade with a bootstrap value of 64 (Figure 2). As same as haplotype analysis, Grobogan I and Grobogan III separate into its own haplotype. Bootstrap represent the reliability of the tree topology. The higher of bootstrap value suggest the higher of the confidence level of the tree [16]. Polytomy on this tree shows that the $L E A F Y$ second intron become less suitable for the study of phylogenies between individuals of $A$. muelleri. However, at the infrageneric level, $L E A F Y$ second intron was able to distinguish between closely related species [8].

\section{Neighbor joining}

Tree topology from neighbo-joining method shows that in almost all samples in-group (except two individuals Grobogan) are on one branch or polytomy like in MP, with a bootstrap value of 72 (Figure 3). Polytomy is a branch that has more than two groups of lineage. Polytomy probably caused by evolution that occurred 


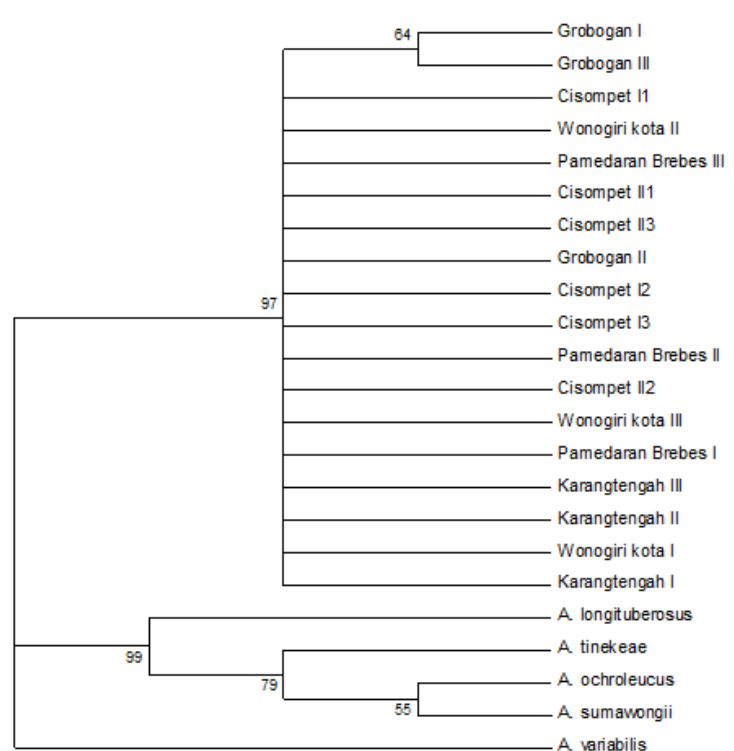

Figure 2. Phylogenetic tree with Maximum parsimony method (bootstrap 1000) of $L E A F Y$ second intron sequences

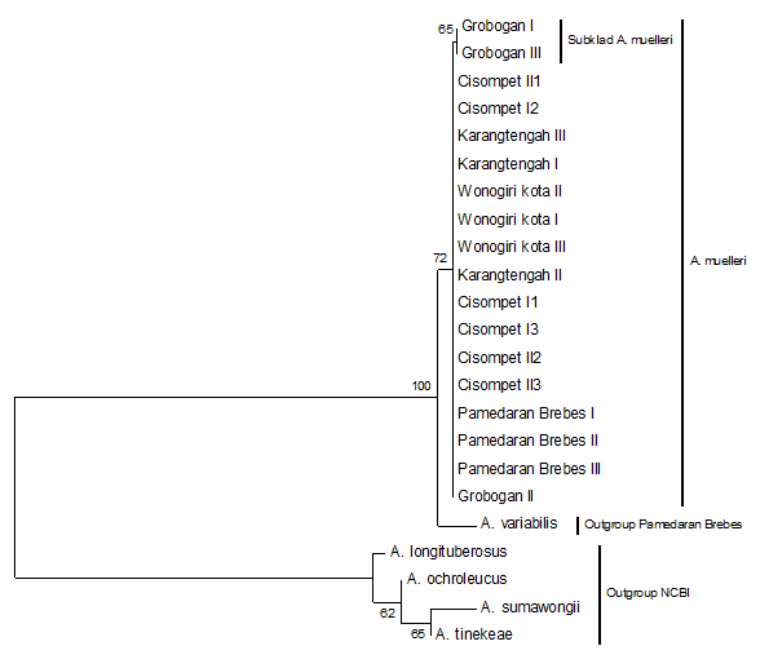

0.1

Figure 3. Phylogenetic tree with Neighbor-Joining method (bootstrap 1000) of $L E A F Y$ second intron sequences

simultaneously at the same time and the uncertainty of phylogenetics [17]. While the individual Grobogan forms a separate sub-clade with a bootstrap value of 65 , as same as haplotypes analysis, where Grobogan I and Grobogan III form their own haplotype and distinct from the other in-group samples. Wahyudi et al., [4] stated that porang of Grobogan is porang cultivation. Mostly, There is human intervention in cultivated plants to improve the development and breeding of plants, for example in the case of parental selection, and it will generate a genetic recombination of both parents. In contrast to the wild porang, which is not yet known how their origins, because porang can re- produce vegetatively and generatively. In the field, porang allegedly doing more vegetative propagation rather than generative, so that there is less genetic variation.

\section{Maximum likelihood}

Analysis using Maximum likelihood method also results in polytomy tree in the in-group samples where one branch has more than two individuals $A$. muelleri (Figure 4) with a bootstrap value of 38 . However, as a neighbor-joining tree, Grobogan I and Grobogan III forming a separate sub-clade with 82 in bootstrap value. The difference with the tree of neighbor-joining method is the bootstrap values. The bootstrap values of maximum likelihood is smaller than the neighbor-joining method in a branch of in-group samples. Values of bootstrap between 70-100 indicate that the branching of the phylogenetic tree will not change, conversely, if the bootstrap value is less than 70 then the chances of branching rearrangement are very high [18].

This polytomy indicates that the $L E A F Y$ second intron is not suitable for detecting kinship between individuals of $A$. muelleri. This low genetic variation suspected that there was association between variations in morphology of $A$. muelleri's flower with $L E A F Y$, this was due to the $A$. muelleri's flower generally not used as distinguishing characteristics between individuals of A. muelleri. The different results are shown by Wahyudi et al. [4] using trnL intron which is a chloroplast genome. The phylogenetic tree shows the separation of the in-group samples into two sub-clade of West Java and Central Java, so it can be said that in

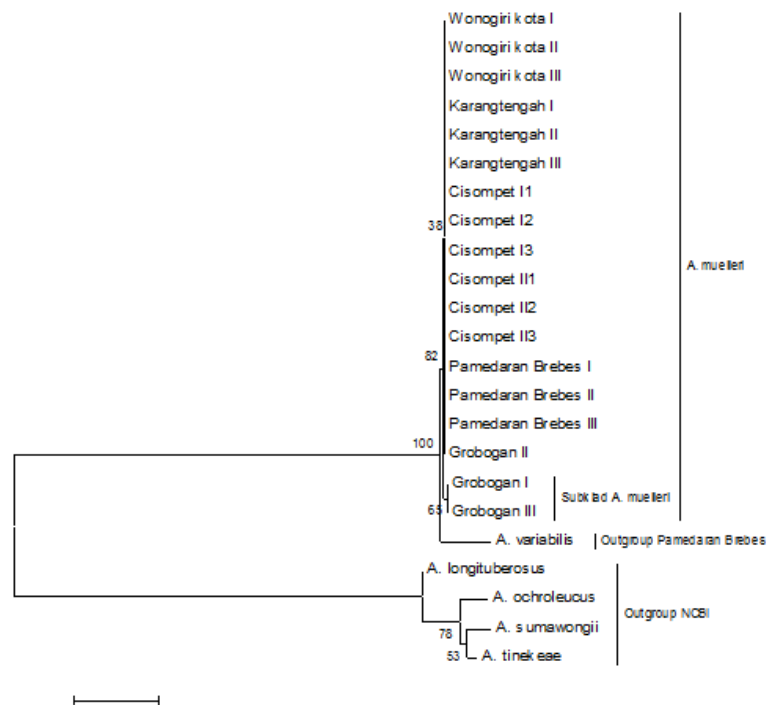

Figure 4. Phylogenetic tree with Maximum Likelihood method (bootstrap 1000) of LEAFY second intron sequences 
this case, the marker from chloroplast genome could be more informative and more varied at infraspecific level than the nuclear genome to show kinship of porang from Central Java and West Java. Genetic variation is higher in the chloroplast genome thought to be influenced by its role in photosynthesis to adapt to the environment.

\section{CONCLUSIONS}

Analysis using dnasp5 showed that 23 samples had 89 invariable sites and 139 variable sites. The total of haplotype were seven haplotypes where 16 in-group samples clumped on haplotype 1 whereas 2 samples of Grobogan (Grobogan I and Grobogan III) clumped on haplotype 2, and out-group samples occupied at their own haplotype. The genetic distance of all in-group samples was 0-0,004. Analysis of phylogenetic tree resulting a polytomy branch of in-group samples except Grobogan, which forms a separated sub-clade.

\section{ACKNOWLEDGMENT}

The authors gratefully acknowledged to P4I (Pusat Penelitian dan Pengembangan Porang Indonesia) whose supported this research. We thank our Biomolecular Divisions who provided facilities, insight and expertise that greatly assisted the research.

\section{REFERENCES}

1. Sumarwoto (2005) Iles-iles (Amorphophallus muelleri Blume); deskripsi dan sifat-sifat lainnya. Jurnal Biodiversitas 6:185-190.

2. Jansen PCM, van der Wilk C, Hetterscheid WLA (1996) Amorphophallus Blume ex Decaisne. (eds.). In Proceeding of PROSEA: Plant Resources of South-East Asia No 9. Plant Yielding Non-seed Carbohydrates: Leiden Edited by Flach M. and F. Rumawas: Backhuys Publishers.

3. Rosidiani EP, Estri LA, Rodiyati A (2013) Analisis variasi genetik Amorphophallus muelleri Blume dari berbagai populasi di Jawa Timur berdasarkan sekuen intron trnL. Floribunda 4(6): 129-137.

4. Wahyudi D, Rodiyati A, Retno M. (2013). Genetic variability of porang populations (Amorphophallus muelleri) in West Java and Central Java based on trnL intron sequence. Journal of Biodiversity and Environmental Sciences 3: 31-41.

5. Yuzammi (2000) A taxonomic revision of the terestrial and aquatic aroid (Araceae) in Java. Thesis. School of Biological Science, Faculty of Life Science. University of
New South Wales.

6. Poerba, Yuyu S, Diyah M (2008) Genetic diversity based on Random Amplified Polymorphic DNA (RAPD) markers in Amorphophallus muelleri Blume in Java. Technology 9: 245-249.

7. Maftuchah (2001) Strategi pemanfaatan penanda molekuler dalam perkembangan bidang hortikultura. Makalah Sarasehan Pemanfaatan Penanda Molekuler di Bidang Hortikultura. Indonesian Biotechnology Information Centre (IndoBIC) Bogor.

8. Sedayu A, Eurlings MCM, Gravendeel B, Hetterscheid WLA (2010) Morphological character evolution of Amorphophallus (araceae) based on a combined phylogenetic analysis of trnL, rbcL and $L E A F Y$ second intron sequences. Botanical Studies 51: 473-490.

9. Wilson CA (2003) Phylogenetic relationships in iris series californicae based on ITS sequences of nuclear ribosomal DNA. Systematic Botany.

10. Grob GBJ, Gravendeel B, Eurlings MCM (2002) Potential phylogenetic utility of the nuclear FLORICAULA/LEAFY second intron: comparison with three chloroplast DNA regions in Amorphophallus (araceae). Journal of Molecular Phylogenetic and Evolution 30:13-23.

11. Drobyazina PE, Emil EK (2011) LEAFY intron 2-based markers of wild Solanum Genomes for introgression breeding thirteenth euroBlight workshop: 9-12 October 2011; St. Petersburg (Russia);

12. Oh SH, Potter D (2003) Phylogenetic utility of the second of LEAFY in Neillia and Stephanandra (rosaceae) and implications for the origin of Stephanandra. Molecular Phylogenetics and Evolution 29: 203-215.

13. Zheng L, Zhang Q, Sun R, Kong H, Zhang N, Hong Ma. (2014) Resolution of deep angiosperm phylogeny using conserved nuclear genes and estimates of early divergence times. Nature Communications.

14. Yingzhi LC, Yunziang T, Nengguo, Xiuxin D (2007) Phylogenetic analysis of mandarin landraces, wild mandarin and related species in China using nuclear $L E A F Y$ second intron and plastid trnL-trnF sequence. Journal of the American Society for Horticultural Science 132 (6): 796-806.

15. Finkeldey R (2005) Pengantar Genetika Hutan Tropis. Terjemahan Djamhuri E, Siregar IZ, Siregar UJ, Kertadikara AW.

16. Nei M, Kumar S (2000) Molecular evolution, phylogenetics. Oxford: University Press. New York.

17. Kuhn TS, Mooers A, Thomas GH (2011) A simple polytomy resolver for dated phylogenies. Methods in Ecology and Evolution 2: 427-436.

18. Simpson MG (2006) Plant systematic. San Diego: Elsevier Academic Press. 